УДК 34.01

\title{
ВОПРОСЫ ПРАВОВОГО РЕГУЛИРОВАНИЯ ПРИОРИТЕТНЫХ НАПРАВЛЕНИЙ МЕДИЦИНСКОЙ ДЕЯТЕЛЬНОСТИ В ИСТОРИИ И СОВРЕМЕННЫХ РЕАЛИЯХ
}

\begin{abstract}
Печникова Ольга Глебовна докт. юр. н., доцент, профессор кафедры теории и истории государства и права ФБОУ ВО РГУ нефти и газа (национальный исследовательский университет) имени И.М. Губкина

Аннотация: автор исследует вопросы правового регулирования приоритетных направлений медицинской деятельности посредством обращения к конституционным нормам и положениям Федерального закона «Об основах охраны здоровья граждан в Российской Федерации». Проводится сравнение подходов и содержания предмета нормативного закрепления, направленного на реализацию преемственности, понимание вовлеченности и правовой ответственности государства, его органов, медицинских организаций и, наконец, каждого члена общества в сферу охраны здоровья. Делается вывод об отличительных особенностях сегодняшних реалий, демонстрирующих крайнюю необходимость усовершенствования дальнейшей стратегии в деле охраны здоровья с использованием новейших достижений в развитии науки, направленных на улучшение здоровья людей и достижение экономического

Ключевые слова: история медицинского права России, законы о медицинской деятельности, нормативно определенные принципы охраны здоровья, о Федеральном законе «Об основах охраны здоровья граждан в Российской Федерации», законотворчество в XVII - начале XIX вв., регламентация вопросов охраны здоровья в России.
\end{abstract} прогресса. 


\title{
ISSUES OF LEGAL REGULATION OF PRIORITY AREAS OF MEDICAL ACTIVITY IN HISTORY AND MODERN REALITIES
}

\section{Pechnikova O.G.}

\begin{abstract}
The author examines the issues of legal regulation of priority areas of medical activity by referring to the constitutional norms and provisions of the Federal Law "On the Fundamentals of Health Protection of Citizens in the Russian Federation." A comparison is made of the approaches and content of the subject of normative consolidation aimed at the implementation of continuity, understanding the involvement and legal responsibility of the state, its bodies, medical organizations and, finally, each member of society in the field of health protection. The conclusion is made about the distinctive features of today's realities, demonstrating the urgent need to improve further strategies in health protection using the latest advances in the development of science aimed at improving human health and achieving economic progress.
\end{abstract}

Key words: history of medical law in Russia, laws on medical activity, normatively defined principles of health protection, on the Federal Law «On the Fundamentals of Health Protection of Citizens in the Russian Federation», lawmaking in the 17th - early 19th centuries, regulation of health protection issues in Russia

Ст. 41 Конституции РФ закрепляет право на охрану здоровья в нашей стране; этим же вопросам, но уже в более детальном рассмотрении, уделено значительное внимание в Федеральном законе «Об основах охраны здоровья граждан в Российской Федерации» № 323-Ф3 от 21.11.2011 (ред. от 30.04.2021). Последний из нами названных нормативных документов, регулирует общие положения; принципы охраны здоровья, соблюдающиеся при взаимодействии всех ветвей власти с обеспечением контроля и правовой ответственности, организацию и осуществление медицинской деятельности при соблюдении прав и обязанностей, предусмотренных основным законом государства [1].

Исследование исторического процесса эволюции правового регулирования медицинской деятельности позволяет проанализировать современные демократические итоги и наметить новые вехи процесса законотворчества. Истоки медицинской деятельности лежат в постепенном 
формировании потребности в государственной организации обеспечения лекарственными средствами и их применения для все более расширяющегося контингента [2].

В самом начале производства стоял Аптекарский приказ, являясь дворцовым ведомством, он организовывал поставки лекарств и медицинских материалов из-за границы для монарха, членов его семьи, бояр, князей и военных. Общим для Аптекарского приказа (образованного в 1581 г.) и Медицинской канцелярии (с 1721 г.) была ориентация на импорт, несмотря на то, что, преимущественно Медицинская канцелярия, прикладывала все возможные усилия для организации поставок отечественного сырья. Медицинская коллегия (с 1763 г.) сыграла большую роль в становлении фармацевтической промышленности и производства вакцин в России, позволивших перенаправить изготовление лекарств на использование не только растительного сырья, но и достижений отечественной науки, более проявившееся с образованием в 1803 г. Медицинского департамента Министерства внутренних дел. Для поддержки отечественного производства лекарств и медицинских материалов, государство придерживалось протекционистской политики в отношении заключения контрактов, а также дальнейшего использования лекарств и «медицинских материалов», что привело к тому, что к началу XIX в., в 2,5 раза сократились ассигнования на их импорт [5]. Остановимся еще на одном важном вопросе.

Так, возможности участия медиков в проведении медицинской экспертизы, удалось достигнуть при Петре I: Устав воинский 1716 г. определял проведение медицинского освидетельствования больных «комиссаром» (в этом случае состояние здоровья не оценивал медик-профессионал) или лекарем. Экспертизу лиц, умерших насильственной смертью, производили лекари; им надлежало «свидетельство в суде на письме подать». Сенатский указ 1759 г. «Об осматривании воеводам и губернаторским товарищам офицеров, отпущенных на рекреацию и отзывающихся от явки в Санкт-Петербург на смотре болезнями», определял периодичность проведения экспертиз[3].

Понимание законодателем экономической выгоды, связанной с возможностью проведения периодических повторных медицинских освидетельствований, послужило принятию указа 1763 г. «О не определении инвалидов в Троицкую Лавру; о ежегодном пересмотре губернаторам или товарищам их, находящихся при монастырях и богадельнях нижних чинов и о 
рапортовании Военной коллегии, ежели из них окажутся способные быть в гарнизоне, у дел или на поселении». Определение четырехмесячного периода, требующегося для вынесения экспертного решения о временной или стойкой нетрудоспособности, а также проведение ежегодных переосвидетельствований подлежащего контингента во многом сохранили актуальность и в современности, являясь достижением Медицинской коллегии [4].

На процессе институционализации нормативно-правового регулирования и организации медицинской экспертизы отразилось государственное реформирование, связанное с Манифестом «Об учреждении министерств» 1802 г.: Медицинская коллегия была включена в состав Министерства внутренних дел, под руководством Министра внутренних дел. Согласно именному указу, данному Сенату «О присоединении дел Медицинской коллегии к ведомству Департамента внутренних дел, под именем Экспедиции государственной медицинской управы; о установлении при департаменте сем Медицинского совета; о упразднении затем, Медицинской коллегии и об отнесении дел по Приказам общественного призрения из третьей во вторую того департамента Экспедицию»1803 г., - регламентировался порядок контроля за выдачей экспертных заключений «в следственных, уголовных и гражданских делах, требующих знания медицинской науки» и разработки соответствующих наставлений [5].

Делая сравнение подходов и содержания предмета правового регулирования приоритетных направлений медицинской деятельности в России в ретроспективе и современных реалиях, мы сможем рассмотреть реализацию преемственности, глубинной многовековую осмысленность, понимание вовлеченности и правовой ответственности государства, его органов, медицинских организаций и, наконец, каждого члена общества в сферу охраны здоровья. Несомненным отличием сегодняшнего дня является все возрастающее понимание крайней необходимости усовершенствования дальнейшей стратегии в деле охраны здоровья с использованием новейших достижений в развитии науки и наиболее оправданного инструмента законодателя, в конечном итоге, направленных на улучшение здоровья людей и достижение экономического прогресса. 


\section{Список литературы}

1. Федеральный закон «Об основах охраны здоровья граждан в Российской Федерации» № 323-Ф3 от 21.11.2011 (ред. от 30. 04. 2021).

2. Памятники литературы Древней Руси. XIII в. // Пер. Д.С. Лихачева. M., 1981. $-650 \mathrm{c}$.

3. Полное собрание законов Российской империи. Собр. 1. Т. XXIX. СПб., 1830. № 22282.

4. Печникова О.Г. Органы управления государственной медициной России с XVI до начала XIX вв.: правовое положение, структура, функции. Абакан: Сервисный пункт, 2014. - 154 с.

5. Печникова О.Г. Государственно-правовое регулирование охраны «народного здравия» в России XVI - начала XIX в. Монография. М.: Юрлитинформ, 2016. - 496 с. 